\title{
GROWTH AND REPRODUCTIVE PERFORMANCE OF EISENIA FOETIDA IN COW MANURE, COW MANURE + SUGARCANE BAGASSE, AND COW MANURE + SAWDUST WASTE
}

\author{
MAHBOUB KHOMAMI, A. ${ }^{1 *}$-MAMMADOV, G. M. ${ }^{2}$-FATEMICHOKAMI, A. ${ }^{3}$ - \\ SEDAGHATHOOR, $\mathrm{S}^{4}$ \\ ${ }^{I}$ Ornamental Plants and Flowers Research Station of Lahijan, Agricultural Research, \\ Education and Extension Organization, Iran \\ (phone: +98-141-222-0059; fax: +98-141-222-0889) \\ ${ }^{2}$ Soil Science and Agrochemestry Institute, Academy of Sciences of Azerbaijan, \\ Baku, Azerbaijan \\ (phone: +99-477-3737225; fax: +99-412-510-1511) \\ ${ }^{3}$ Tea Research Institutes of Iran, Lahijan, Gilan, Iran \\ (phone: +98-134-242-4001; fax: +98-134-242-5575) \\ ${ }^{4}$ Department of Horticulture, Rasht branch, Islamic Azad University, Rasht, Iran \\ (phone: +98-133-342-083; fax: +98-133-342-083) \\ *Corresponding Author \\ e-mail:Mahboub48@yahoo.com \\ (Received $9^{\text {th }}$ Aug 2014; accepted $17^{\text {th }}$ Dec 2015)
}

\begin{abstract}
Accumulation of sawdust and sugarcane bagasse can cause serious problems for the environment. In this study, we examined the growth and reproductive performance of Eisenia foetida in cow manure, cow manure + sugarcane bagasse $(4: 1, \mathrm{~V} / \mathrm{V})$ and cow manure + sawdust $(4: 1, \mathrm{~V} / \mathrm{V})$ waste and its effects on $\mathrm{CO}_{2}$ evolution. The results showed that the weight gain for $E$. foetida (live weight) per gram of dry weight of the feed source in cow manure + sugarcane bagasse $(39 \pm 0.66 \mathrm{mg} / \mathrm{g})$ and cow manure waste $(37 \pm 0.36 \mathrm{mg} / \mathrm{g})$ were greater than in cow manure + sawdust waste $(34 \pm 1.05 \mathrm{mg} / \mathrm{g})$. The number of cocoons produced per earthworm per day in different wastes was in the order: cow manure + sugarcane bagasse > cow manure + sawdust $>$ cow manure. After adding earthworms to cow manure, cow manure + sugarcane bagasse, and cow manure + sawdust, $\mathrm{CO}_{2}$ emissions rapidly decreased after 15 days. Statistical analysis showed that after 90 days, vermicompost wasn't significantly different $(p=0.05)$ from compost in terms of production of nitrogen, phosphorus, potassium and $\mathrm{pH}$ level. Our experiments presented vermicomposting using E. foetida as an alternative technology that can be used to recycle $\mathrm{S}$ and SB in laboratory conditions.
\end{abstract}

Keywords: earthworms, cocoon, waste, growth, $\mathrm{CO}_{2}$, microbial biomass, physicochemical characteristics

\section{Introduction}

Over the last few years, the interest in using earthworms as an ecological system for manure management has tremendously increased. Various researchers have tested earthworm-processed wastes, usually called vermicompost in the horticulture and agriculture industries (Atiyeh et al., 2004; Arancon et al., 2005; Azizi, et al., 2008). During vermicomposting process, the important plant nutrients, such as nitrogen, potassium, phosphorous and calcium present in feed material are converted into much more soluble and available to plants than those in the parent compounds (Ndegwa and Thompson, 2001). Because of the uniformity of its composition, vermicompost reduces 
pollutants and tends to hold more nutrients over a longer period without any impact on the environment and is considered an excellent product.

The potential of Perionyx excavates in vermicomposting of different wastes, such as sheep dung, cow dung, biogas sludge, and poultry manure, was reported by Kale et al. (1982). Loh et al. (2004) reported higher cocoon production and weight gain by $E$. foetida in cattle waste than in goat waste. Gunadi and Edwards (2003) have studied growth, reproduction, and mortality of E. foetida for over a year in solid manure, pig manure, and supermarket waste solids. Worms could not survive in fresh cattle solids, pig solids, fruit wastes, or vegetable wastes. The growth of E. foetida in pig wastes was faster than in cattle solids. After 60 weeks of the experiment, several times of adding the substrate increased reproduction of worms, but worms showed a tendency to lose weight. Organic matter, microorganisms, and plants are some components of the environment that continually influence agricultural systems (Silvana et al., 2001).

During vermicomposting, earthworms eat and grind substrates, convening with anaerobic micro flora to increase the surface area for microbial colonization and enzymatic action (Edwards and Fletcher, 1988). E. foetida is an epigeic earthworm species that lives in organic wastes and requires high moisture content, adequate amounts of suitable organic material, and dark conditions for proper growth and development (Gunadi and Edwards, 2003; Gunadi et al., 2002).

Throughout the world, earthworms play an important role in determining the balance of greenhouse gases from soils, and their impact is expected to increase in the coming decades (Lubbers et al., 2013). Respiratory CO2 (a measure of metabolic activities) and the enzymes involved in the various chemical changes in the soil are usually used as the index in some laboratory studies in which manure in incubators is modified over several weeks by the addition of earthworms. It showed that earthworms greatly reduce respiration and soil enzyme activities (Pichtel and Hayes, 1990).

This paper aims to investigate the effect of $\mathrm{CM}, \mathrm{CM}+\mathrm{SB}$, and $\mathrm{CM}+\mathrm{S}$ waste on the life cycle of E. foetida and its effects on $\mathrm{CO} 2$ evolution. It was hypothesized that $\mathrm{S}$ and SB waste would affect the life cycle of E. foetida due to differences in physico-chemical characteristics.

\section{Material and Methods}

Three treatment groups were studied in triplicate, containing a mixture of cow manure $(\mathrm{CM})$ alone, cow manure $(\mathrm{CM})+$ sugarcane bagasse $(\mathrm{SB})$, and cow manure $(\mathrm{CM})+$ sawdust $(\mathrm{S})$, all with a ratio of $4: 1(\mathrm{~V} / \mathrm{V})$, respectively.

\section{Growth, sexual development, and cocoon production}

Nine one liter plastic containers (Three treatments in the three replicates) (diameter $12 \mathrm{~cm}$, depth $10 \mathrm{~cm}$ ) were filled with $150 \mathrm{~g}$ (air dry) of CM + EW (earthworms), CM + $\mathrm{SB}+\mathrm{EW}$, and $\mathrm{CM}+\mathrm{S}+\mathrm{EW}$. To eliminate the escape of toxic gases, wastes were manually stirred daily over a period of 15 days. After fifteen days, seven non-clitlellated hatchlings of E. foetida, weighing 200-250 mg (live weight), were placed into a container. The moisture content of the waste was kept within the range of $80-70 \%$ humidity throughout the study period. Growth chamber had an internal stabilization system for temperature and humidity, but to make sure of enough moisture, distilled water was sprayed. All containers were kept in a dark growth chamber at $25 \pm 1^{\circ} \mathrm{C}$ (Figure 3). Weight gain, clitellum development, and cocoon production were recorded 
weekly for 12 weeks (Figure 4). The feed was removed from the container, and earthworms and cocoons were separated from the feed by hand sorting. After counting them, the development clitellum was examined and weighed after being washed with water and dried with toilet paper. The worms were weighed without removing their gut contents. For any data obtained in this study, correction for gut contents was not used. Then, all earthworm food (but no cocoons) was returned to the container. No food was added at any stage during the study period. The cocoons viability was determined weekly for 12 weeks by removing them from the plastic containers and putting them in a Petri dish filled with distilled water. All petri dishes were kept in darkness at a temperature of $25 \pm 1{ }^{\circ} \mathrm{C}$. To prevent bacterial growth and avoid negative impacts on the results, the water in these dishes was replaced daily. Cocoons and hatchlings for each cocoon were recorded over a period of 12 weeks.

\section{CO2 evolution}

Eighteen one-liter plastic containers (diameter $12 \mathrm{~cm}$, depth $10 \mathrm{~cm}$ ) were filled with $150 \mathrm{~g}$ (dry air) of CM, CM + SB, CM + S, CM + EW (earthworms), CM + SB + EW, or $\mathrm{CM}+\mathrm{S}+\mathrm{EW}$ (Six treatments in the three replicates). The moisture content of wastes was adjusted in the range of $70-80 \%$ during the study period by spraying adequate quantities of distilled water. All containers were kept in darkness at a temperature $25 \pm$ $1{ }^{\circ} \mathrm{C}$ (Figure 3). Waste was manually stirred daily for 15 days in order to eliminate the escape of toxic gases. The compost (treatments without earthworms) was produced parallel to vermicompost (treatments with earthworms). After the 15 days, seven nonclitlellated hatchling of E. foetida, weighing 200-250 milligrams (live weight), were placed in each vermicompost container. Samples were taken at 0, 15, 30, 45, 75, and 90 days. Day 0 refers to the initial mixing of the waste before preliminary decomposition. Earthworms collected by hand sorting and the wastes without earthworms were evaluated for $\mathrm{CO}_{2}$ evolution. The alkali trap method was used to quantify the released $\mathrm{CO}_{2}$ (Anderson, 1982). Conical respiration flasks $(500 \mathrm{~mL})$ contained the earthworm treatments and assimilation vials that each contained $10 \mathrm{~mL}$ of $0.3 \mathrm{M} \mathrm{NaOH}$. Flasks containing the alkali traps alone served as controls. The Alkali traps were replaced in each of the samples, and were titrated with $0.1 \mathrm{M} \mathrm{HCl}$ (Anderson, 1982). The evolved $\mathrm{CO}_{2}$ obtained from the titration data was corrected with control data. All experiments were performed in triplicate, and the results were averaged.

\section{Physicochemical analysis}

The $\mathrm{pH}$ was determined in a double distilled water suspension of each mixture with a ratio of 1:5 (W/V) that had been shaken mechanically for 30 min and filtered through a whatman No.1 filter. The electrical conductivity of this solution was measured by a conductivity meter (Verdonck and Gabriels, 1992). For all samples, total nitrogen was determined by the Bremner and Mulvaney (1982) procedure after digesting the sample with concentrated $\mathrm{H} 2 \mathrm{SO} 4$ and $\mathrm{HClO} 4(9: 1, \mathrm{~V} / \mathrm{V})$. Each sample $(2 \mathrm{~g})$ was ashed in a muffle furnace at $550^{\circ} \mathrm{C}$ for determination of other nutrients (Horwitz, 1980). The white ash was then dissolved in $2 \mathrm{~N} \mathrm{HCl}$, and distilled water was added to bring the total volume to $100 \mathrm{~mL}$. Total $\mathrm{P}$ was measured with spectrophotometer by using the Murphy and Riley (1962) procedure with molybdenum in sulfuric acid. Total K was measured with a flame photometer using the Houba et al., (1989) method, after digesting the 
sample in the diacid mixture (concentrated $\mathrm{HNO}_{3}: \mathrm{HClO}_{4}, 4: 1, \mathrm{~V} / \mathrm{V}$ ). The Nelson and Sommer (1982) method was used to measure total organic carbon.

\section{Statistical analyses}

The data were analyzed by SAS and means were compared by Tokay's multiple range tests at $5 \%$ probability level (SAS Institute, 2001).

\section{Results}

The primary physicochemical properties by $\mathrm{CM}, \mathrm{SB}, \mathrm{S}, \mathrm{CM}+\mathrm{S}$ and $\mathrm{CM}+\mathrm{SB}$ waste are summarized in Table 1. The waste moisture varied between $14.40 \%$ and $15.20 \%$. The highest electrical conductivity was in SB waste $(3.19 \mu \mathrm{S} / \mathrm{cm})$ and the lowest was in $\mathrm{S}$ waste $(0.46 \mu \mathrm{S} / \mathrm{cm})$. The $\mathrm{OC}$ ranged from $23.24 \%$ in $\mathrm{CM}+\mathrm{SB}$ waste to $57.18 \%$ in $\mathrm{S}$ waste. The $\mathrm{C} / \mathrm{N}$ ratio was the lowest in $\mathrm{CM}+\mathrm{SB}$ waste and the highest in $\mathrm{S}$ waste, 12.16 and 181.81, respectively. The potassium content ranged from of $0.40 \%$ in SB waste to $1.11 \%$ in $\mathrm{CM}+\mathrm{S}$ waste. Phosphorus ranged from $0.04 \%$ in $\mathrm{SB}$ waste to $0.56 \%$ in $\mathrm{CM}+\mathrm{SB}$ waste.

Table 1. First physicochemical characteristics of $C M, S B$ and $S$ waste.

\begin{tabular}{ccccccccc}
\hline Waste & $\begin{array}{c}\text { Moisture } \\
\text { content }(\%)\end{array}$ & $\begin{array}{c}\mathrm{pH} \\
(1: 5)\end{array}$ & $\begin{array}{c}\text { Conductivity } \\
(\mu \mathrm{S} / \mathrm{cm})\end{array}$ & $\begin{array}{c}\mathrm{OC} \\
(\%)\end{array}$ & $\begin{array}{c}\mathrm{N} \\
(\%)\end{array}$ & $\begin{array}{c}\mathrm{C} / \mathrm{N} \\
\text { ratio }\end{array}$ & $\begin{array}{c}\mathrm{K} \\
(\%)\end{array}$ & $\begin{array}{c}\mathrm{P} \\
(\%)\end{array}$ \\
\hline $\mathrm{CM}$ & 14.40 & 8.15 & 2.06 & 47.30 & 1.24 & 38.12 & 0.62 & 0.29 \\
$\mathrm{~S}$ & 14.85 & 7.37 & 0.46 & 57.18 & 0.31 & 181.81 & 0.61 & 0.34 \\
$\mathrm{SB}$ & 15.05 & 7.79 & 3.19 & 50.23 & 0.45 & 111.75 & 0.40 & 0.04 \\
$\mathrm{CM}+\mathrm{S}$ & 15.14 & 7.20 & 2.00 & 23.62 & 1.73 & 13.68 & 1.11 & 0.78 \\
$\mathrm{CM}+\mathrm{SB}$ & 15.20 & 8.47 & 2.99 & 23.24 & 1.91 & 12.16 & 0.86 & 0.56 \\
\hline
\end{tabular}

CM, cow manure; SB, sugarcane bagasse; S, sawdust; OC: Organic Carbon

\section{Growth of E. foetida in the wastes}

No mortality was observed in any waste during the study period. In this experiment, all waste was stirred by hand daily for 15 days to prevent the accumulation of toxic gas. The growth rate of E. foetida in investigating waste during the study period is given in Figure 1.

Maximum worm weight was obtained in $\mathrm{CM}+\mathrm{SB}$ waste $(621 \pm 119 \mathrm{mg} /$ earthworm $)$ and minimum in $\mathrm{CM}+\mathrm{S}(557 \pm 490 \mathrm{mg}$ /earthworm $)$. Maximum earthworm weight was obtained in the $7^{\text {th }}, 9^{\text {th }}$, and $12^{\text {th }}$ week, for $\mathrm{CM}, \mathrm{CM}+\mathrm{SB}$, and $\mathrm{CM}+\mathrm{S}$ waste, respectively. Initially, the earthworms gained weight, but after a few weeks, earthworm weight loss was observed in all waste groups. This earthworm weight loss can be attributed to the depletion of food. The highest weight per g dry weight of food for $E$. foetida was obtained in CM $+\mathrm{SB}$ waste $(39 \pm 0.66 \mathrm{mg} / \mathrm{g})$ and the lowest in CM $+\mathrm{S}(34 \pm$ $1.05 \mathrm{mg} / \mathrm{g}$ ) waste. The weight gain in our study was only $37 \pm 0.66 \mathrm{mg} / \mathrm{g}$ by $E$. foetida species in $\mathrm{CM}$ at $25^{\circ} \mathrm{C}$.

Net weight gain/earthworm per unit of food material in different feeds will follow this order: $\mathrm{CM}+\mathrm{SB}>\mathrm{CM}>\mathrm{CM}+\mathrm{S}$. Similarly, we found that net weight gain by earthworms in $\mathrm{CM}+\mathrm{SB}$ waste was 1.1 times higher than in $\mathrm{CM}+\mathrm{S}$ waste (Table 2).

Accordingly, the highest growth rate was obtained in waste $\mathrm{CM}+\mathrm{SB}(6.9 \pm 1.18)$ and the lowest growth rate in $\mathrm{CM}+\mathrm{S}(6.1 \pm 1.96)$ (Table 2). 
Table 2. Growth of Eisenia foetida in CM, SB and $S$ waste.

\begin{tabular}{c|c|c|c|c|c|c}
\hline Treatments & $\begin{array}{c}\text { Mean first } \\
\text { weight/ } \\
\text { earthworm } \\
(\mathrm{mg})\end{array}$ & $\begin{array}{c}\text { Maximum } \\
\text { weight } \\
\text { reached } \\
/ \text { worm(mg) }\end{array}$ & $\begin{array}{c}\text { Maximum } \\
\text { weight } \\
\text { reached } \\
\text { on }\end{array}$ & $\begin{array}{c}\text { Net } \\
\text { weight } \\
\text { gain/worm } \\
(\mathrm{mg})\end{array}$ & $\begin{array}{c}\text { Growth } \\
\text { rate } \\
\text { /worm/day } \\
(\mathrm{mg})\end{array}$ & $\begin{array}{c}\text { Worm } \\
\text { weight } \\
\text { each unit } \\
\text { dry waste } \\
(\mathrm{mg} / \mathrm{g})\end{array}$ \\
\hline $\mathrm{CM}$ & $234 \pm 25$ & $618 \pm 123$ & $7^{\text {th }}$ week & $557 \pm 490$ & $6.6 \pm 0.61$ & $37 \pm 0.36$ \\
$\mathrm{CM}+\mathrm{S}$ & $228 \pm 16$ & $557 \pm 490$ & $\begin{array}{c}12^{\text {th }} \text { week } \\
9^{\text {th }} \text { week }\end{array}$ & $\begin{array}{c}513 \pm 166 \\
579 \pm 100\end{array}$ & $6.1 \pm 1.96$ & $6.9 \pm 1.18$ \\
$\mathrm{CM}+\mathrm{SB}$ & $208 \pm 70$ & $621 \pm 119$ & $39 \pm 0.66$ \\
\hline
\end{tabular}

$\mathrm{CM}$, cow manure; SB, sugarcane bagasse; S, sawdust; All values was introduced as the mean \pm SD (standard deviation).

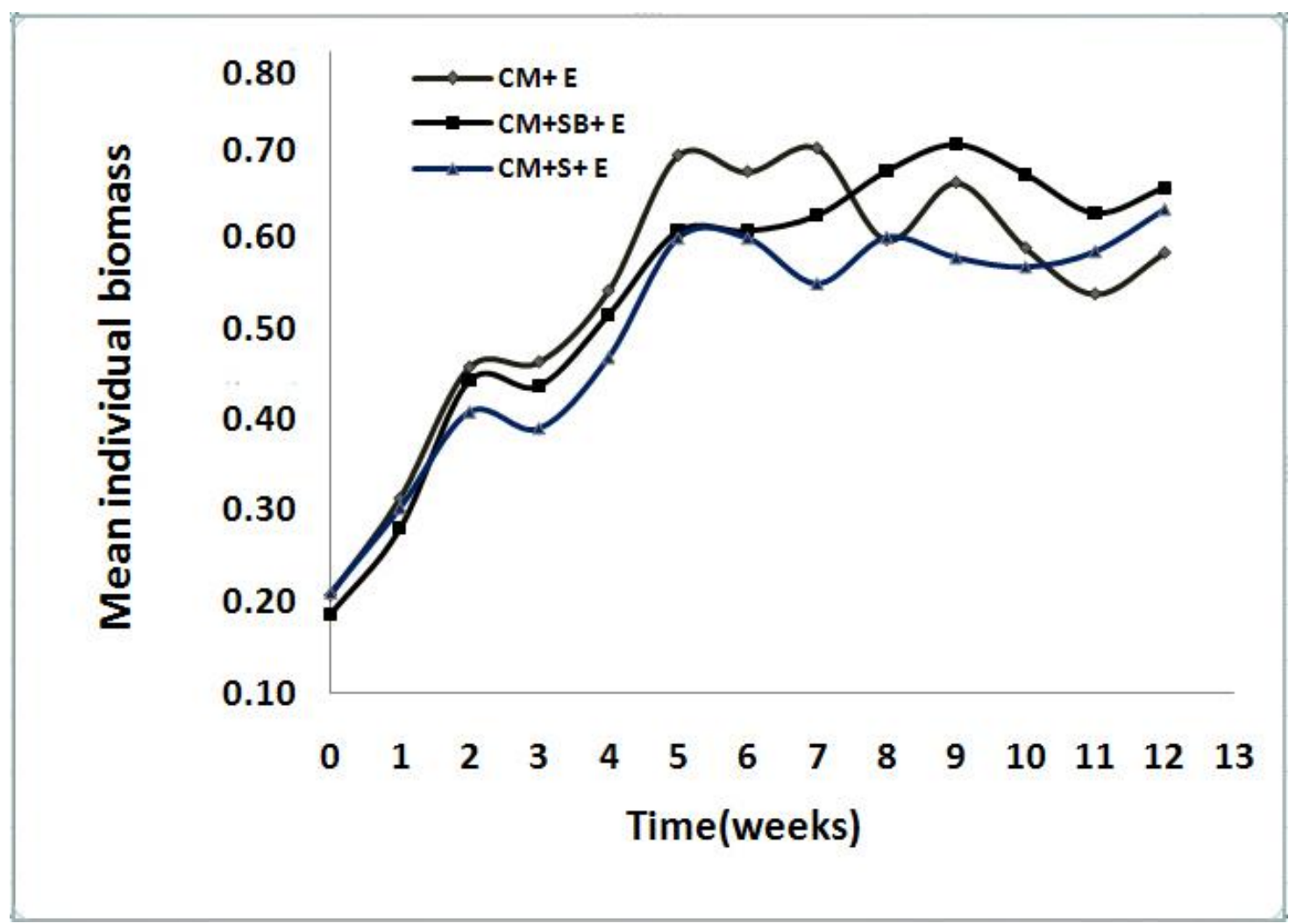

Figure 1. The Eisenia foetida growth on different wastes. Abbreviations: CM, cow manure; SB, sugarcane bagasse; $S$, sawdust; E, earthworms

\section{Sexual development and cocoon production}

Table 3 summarizes the sexual development and cocoon production of earthworms in various feeds. Individual clitellum developed by day 28 in all food types. Cocoon production of earthworms in all waste was started about 35 days. Figure 2 shows the cumulative cocoon production by earthworms in different feeds. After 12 weeks maximum cocoons were found in $\mathrm{CM}+\mathrm{SB}$ waste $(215 \pm 30)$ and minimum in $\mathrm{CM}$ waste $(191 \pm 20)$. 
Table 3. Cocoon production by Eisenia foetida in $C M, S B$ and $S$ waste.

\begin{tabular}{c|c|c|c|c|c|c}
\hline Treatments & $\begin{array}{c}\text { Clitellum } \\
\text { development } \\
\text { started in }\end{array}$ & $\begin{array}{c}\text { Cocoon } \\
\text { production } \\
\text { started in }\end{array}$ & $\begin{array}{c}\text { Total no. } \\
\text { of } \\
\text { cocoons } \\
\text { produced } \\
\text { after } \\
12 \text { weeks }\end{array}$ & $\begin{array}{c}\text { No. of } \\
\text { cocoons } \\
\text { produced/ } \\
\text { worm }\end{array}$ & $\begin{array}{c}\text { No. of } \\
\text { cocoons } \\
\text { produced/ } \\
\text { worm } \\
/ \text { day }\end{array}$ & $\begin{array}{c}\text { Cocoon } \\
\text { production } \\
\text { stopped } \\
\text { after }\end{array}$ \\
\hline $\mathrm{CM}$ & $3^{\text {th }}$ week & $5^{\text {th }}$ week & $191 \pm 20$ & $30.2 \pm 1.70$ & $0.36 \pm 0.02$ & $12^{\text {th }}$ week \\
$\mathrm{CM}+\mathrm{S}$ & $4^{\text {th }}$ week & $5^{\text {th }}$ week & $209 \pm 46$ & $30.8 \pm 4.26$ & $0.37 \pm 0.05$ & $12^{\text {th }}$ week \\
$\mathrm{CM}+\mathrm{SB}$ & $4^{\text {th }}$ week & $5^{\text {th }}$ week & $215 \pm 30$ & $31.5 \pm 6.61$ & $0.38 \pm 0.08$ & $12^{\text {th }}$ week \\
\hline
\end{tabular}

$\mathrm{CM}$, cow manure; SB, sugarcane bagasse; S, sawdust;

All values was introduced as the mean $\pm \mathrm{SD}$ (standard deviation).

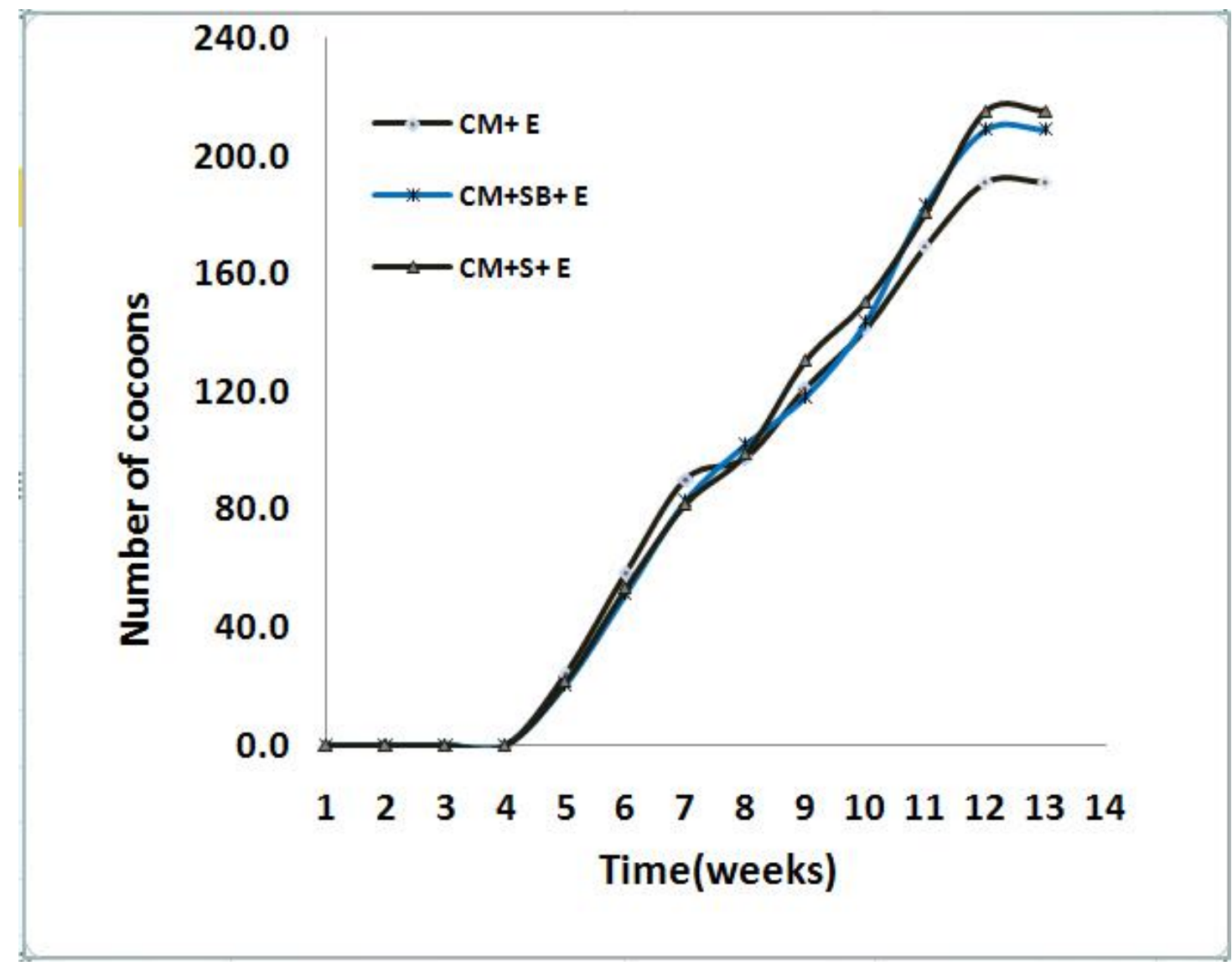

Figure 2. Cumulative cocoon production by Eisenia foetida on different wastes. Abbreviations:CM, cow manure; $S B$, sugarcane bagasse; $S$, sawdust; E, earthworms

Cocoon production of earthworms per day in different waste will follow this order: $\mathrm{CM}+\mathrm{SB}>\mathrm{CM}+\mathrm{S}>\mathrm{CM}$ (Table 4). We suggest that $\mathrm{CM}+\mathrm{S}$ and $\mathrm{CM}+\mathrm{SB}$ waste are good foods for supporting weight and the reproduction of earthworms.

Table 4 summarizes the viability of E. foetida cocoon in $\mathrm{CM}, \mathrm{SB}$, and $\mathrm{S}$ waste. The maximum number of hatchlings was produced after 12 weeks in CM waste $(428 \pm 27)$ and the minimum in $\mathrm{CM}+\mathrm{SB}$ waste $(393 \pm 77)$. Mature worms spend a lot of energy 
producing their cocoons. Cocoon production was stopped by day 84 in all waste conditions.

Table 4. Cocoon viability in $C M, S B$ and $S$ waste.

\begin{tabular}{c|c|c}
\hline Treatments & $\begin{array}{c}\text { Total no. of hatching produced } \\
\text { after 12 weeks }\end{array}$ & $\begin{array}{c}\text { No. of hatching produced/ } \\
\text { cocoons }\end{array}$ \\
\hline $\mathrm{CM}$ & $428 \pm 27$ & $2.3 \pm 0.30$ \\
$\mathrm{CM}+\mathrm{S}$ & $439 \pm 54$ & $2.1 \pm 0.43$ \\
$\mathrm{CM}+\mathrm{SB}$ & $393 \pm 77$ & $1.9 \pm 0.15$ \\
\hline
\end{tabular}

$\mathrm{CM}$, cow manure; $\mathrm{SB}$, sugarcane bagasse; $\mathrm{S}$, sawdust;

All values were introduced as the mean $\pm \mathrm{SD}$ (standard deviation).

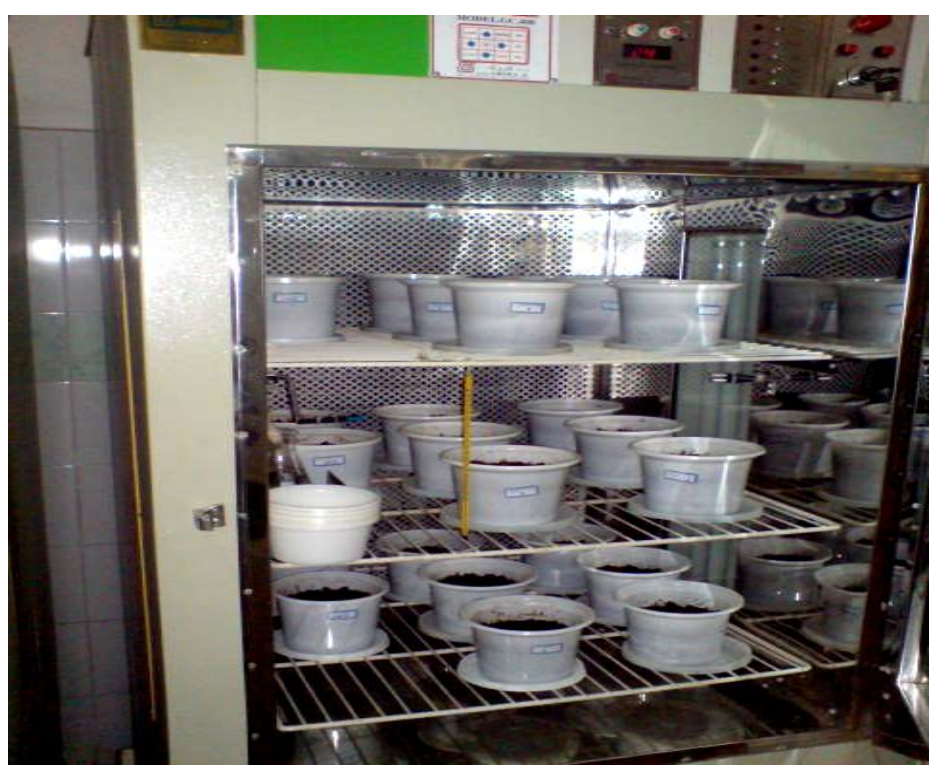

Figure 3. Growth chamber for keeping containers.

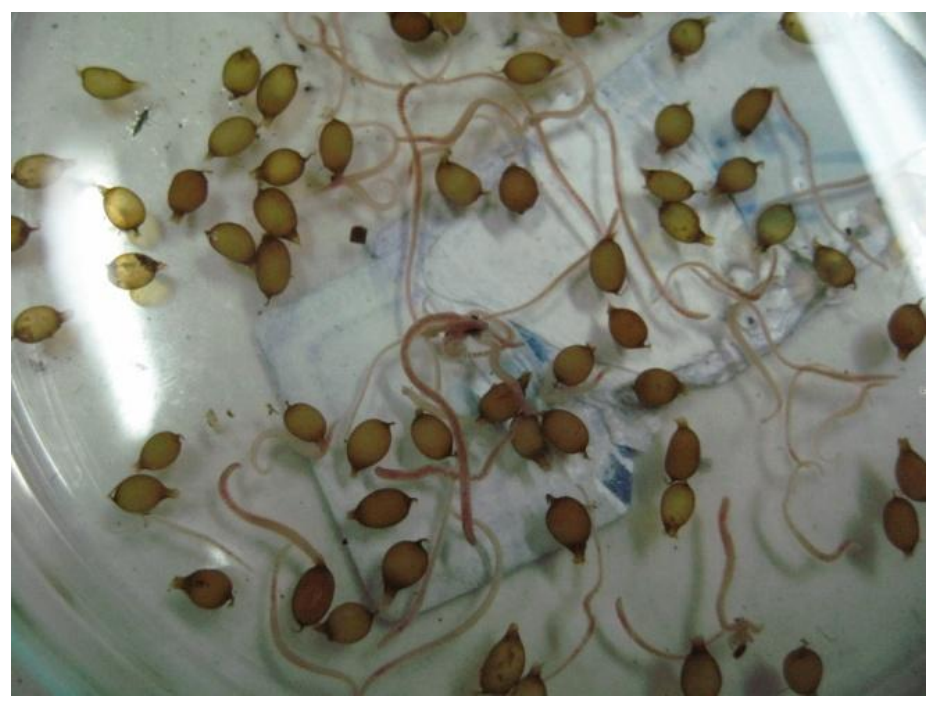

Figure 4. The cocoons of Eisenia foetida and hatchling emerged from them. 
Table 5 shows the results of changes in $\mathrm{CO} 2$ evolution during composting of $\mathrm{CM}, \mathrm{SB}$ and $\mathrm{S}$ waste in the absence and presence of earthworms in a 90-day period. Respiration rate in the studied waste rapidly decreased after 15 days (Table 5). The ratio of $\mathrm{N}, \mathrm{P}, \mathrm{K}$ and $\mathrm{pH}$ in compost inoculated with earthworms wasn't different from compost without worms (Table 6).

Table 5. Change in $\mathrm{CO}_{2}$ evolution $\left(\mu \mathrm{g} \mathrm{CO}_{2} g^{-1} h^{-1}\right)$ during composting of organic wastes

\begin{tabular}{ccccccc}
\hline Treatments & \multicolumn{7}{c}{ Days } \\
\cline { 2 - 7 } & 0 & 15 & 30 & 45 & 75 & 90 \\
\hline CM & $30.4 \mathrm{a}$ & $11.7 \mathrm{bc}$ & $8.4 \mathrm{bd}$ & $5.0 \mathrm{bd}$ & $5.2 \mathrm{bd}$ & $3.8 \mathrm{~cd}$ \\
$\mathrm{CM}+\mathrm{EW}$ & $30.4 \mathrm{a}$ & $8.6 \mathrm{bd}$ & $9.1 \mathrm{bd}$ & $4.0 \mathrm{~cd}$ & $3.4 \mathrm{~cd}$ & $2.4 \mathrm{~d}$ \\
$\mathrm{CM}+\mathrm{S}$ & $26.5 \mathrm{a}$ & $10.1 \mathrm{bd}$ & $7.1 \mathrm{bd}$ & $5.8 \mathrm{bd}$ & $4.5 \mathrm{bd}$ & $4.2 \mathrm{bd}$ \\
$\mathrm{CM}+\mathrm{S}+\mathrm{EW}$ & $26.5 \mathrm{a}$ & $11.2 \mathrm{bc}$ & $7.8 \mathrm{bd}$ & $6.9 \mathrm{bd}$ & $6.0 \mathrm{bd}$ & $4.6 \mathrm{bd}$ \\
$\mathrm{CM}+\mathrm{SB}$ & $28.6 \mathrm{a}$ & $12.5 \mathrm{~b}$ & $7.2 \mathrm{bd}$ & $4.5 \mathrm{bd}$ & $5.2 \mathrm{bd}$ & $4.2 \mathrm{bd}$ \\
$\mathrm{CM}+\mathrm{SB}+\mathrm{EW}$ & $28.6 \mathrm{a}$ & $23.8 \mathrm{a}$ & $8.1 \mathrm{bd}$ & $6.1 \mathrm{bd}$ & $5.3 \mathrm{bd}$ & $5.2 \mathrm{bd}$ \\
\hline
\end{tabular}

Abbreviations: CM, cow manure; SB, sugarcane bagasse; S, sawdust.

Means followed by the same letters do not significantly differ $(p=0.05)$.

Table 6. Physicochemical properties of treatments after 90 days of composting

\begin{tabular}{ccccc}
\hline Treatments & $\begin{array}{c}\text { Total N } \\
(\%)\end{array}$ & $\begin{array}{c}\text { Total P } \\
(\%)\end{array}$ & $\begin{array}{c}\text { Total K } \\
(\%)\end{array}$ & $\begin{array}{c}\text { PH } \\
(1: 5)\end{array}$ \\
\hline $\mathrm{CM}$ & $1.75 \mathrm{a}$ & $0.48 \mathrm{ab}$ & $1.01 \mathrm{ac}$ & $8.11 \mathrm{ab}$ \\
$\mathrm{CM}+\mathrm{E}$ & $1.81 \mathrm{a}$ & $0.50 \mathrm{a}$ & $1.13 \mathrm{ab}$ & $8.00 \mathrm{~b}$ \\
$\mathrm{CM}+\mathrm{S}$ & $1.44 \mathrm{ab}$ & $0.38 \mathrm{bc}$ & $0.88 \mathrm{bd}$ & $7.30 \mathrm{c}$ \\
$\mathrm{CM}+\mathrm{S}+\mathrm{E}$ & $1.47 \mathrm{ab}$ & $0.39 \mathrm{~b}$ & $1.15 \mathrm{a}$ & $7.20 \mathrm{c}$ \\
$\mathrm{M}+\mathrm{SB}$ & $1.53 \mathrm{a}$ & $0.46 \mathrm{ab}$ & $0.74 \mathrm{df}$ & $8.46 \mathrm{a}$ \\
$\mathrm{CM}+\mathrm{SB}+\mathrm{E}$ & $1.67 \mathrm{a}$ & $0.46 \mathrm{ab}$ & $0.82 \mathrm{ce}$ & $8.18 \mathrm{ab}$ \\
\hline
\end{tabular}

Abbreviations: CM, cow manure; SB, sugarcane bagasse; S, sawdust; E, earthworms

Means followed by the same letters do not significantly differ $(\mathrm{p}=0.05)$.

\section{Discussion}

Gunadi and Edwards (2003) reported mortality of E. foetida after two weeks in fresh manure even though factors such as $\mathrm{pH}$, electrical conductivity, the ratio of $\mathrm{C}: \mathrm{N}$, and $\mathrm{NH} 4+$ and NO3 contents were suitable for the growth of earthworms. They believed that the earthworm death were due to anaerobic conditions that had been generated after two weeks in the fresh cow manure. It is acknowledged that to prevent mortality of earthworms, pre-composting is essential.

Neuhauser et al. (1980) reported that the rate of weight gain by E. foetida is dependent on population density and the type of food. According to Edwards et al. (1998), growth rate is a good indicator for comparing the growth of earthworms in different wastes. The weight gain for E. foetida (live weight) per gram dry weight of the feed of CM + SB $(39 \pm 0.66 \mathrm{mg} / \mathrm{g})$ and $\mathrm{CM}(37 \pm 0.36 \mathrm{mg} / \mathrm{g})$ wastes was more than that of $\mathrm{CM}+\mathrm{S}$ wastes $(34 \pm 1.05 \mathrm{mg} / \mathrm{g}$ ). Edwards et al., (1998) reported generation of 292 $\mathrm{mg} / \mathrm{g}$ weight by $P$. excavatus in $\mathrm{CM}$ at $25^{\circ} \mathrm{C}$, but in our study was only $37 \pm 0.66 \mathrm{mg} / \mathrm{g}$ by $E$. foetida species. This difference could be due to difference in species morphology or primary characteristics of the feed wastes. 
Cocoon production rates may be related to biochemical differences between the quality of feeds, which are important in determining the time to reach sexual maturity and begin reproduction (Edwards, 1988; Edwards et al., 1998). Cocoons production per earthworm in each day of treatment observed the following pattern from the highest to the lowest: $\mathrm{CM}+\mathrm{SB}>\mathrm{CM}+\mathrm{S}>\mathrm{CM}$. These wastes can support growth and reproduction of E. foetida, and thus can be used as foods in a large scale vermicomposting facility. Feeds which can provide enough easily metabolizable organic matter and carbohydrates are favorable for earthworm growth and reproduction (Edwards, 1988). When cocoons are not being produced, energy is used for tissue growth (Chaudhari and Bhattacharjee, 2002; Kale et al., 1982). Satchell (1967) showed that the effects of earthworms in readily degradable organic substances, which contain a high microbial population, are not significant in comparison with soil.

Another parameter that represents the stabilization rate in manure containing earthworms is respiration rate (i.e., $\mathrm{CO}_{2}$ production) (Atiyeh et al., 2000). In the first four weeks of the experiment, microbial activity and earthworm activity progressed. The rapid decrease in the rate of evolution of $\mathrm{CO}_{2}$ from the $\mathrm{CM}, \mathrm{CM}+\mathrm{S}$, and $\mathrm{CM}+\mathrm{SB}$ wastes showed that many biodegradable materials were being rapidly destroyed. Two weeks after the addition of earthworms to waste, $\mathrm{CO} 2$ evolution rapidly decreased and continued to more slowly decrease until week 12, which indicates increased stability in organic matter. Similarly, Bautista et al. (2011) reported that more than $70 \%$ of the total $\mathrm{CO}_{2}$ evolution occurs during the first week of the composting process. Generally, activities of earthworms in the soil, enhances the number and biomass of microbes (Edwards and Bohlen, 1996). Zhang et al. (2000) reported that earthworms use microorganisms as a secondary food source; total soil microbial biomass reduced transit time through the earthworm gut, while active components of microbial biomass increased transit time. The results correspond with the results of Grapelli et al. (1983), who noted that earthworms selectively support the microorganisms that are responsible for the transformation of organic matter in the soil. This can be attributed to the effect of earthworms on organic acid accumulation resulting from microbial metabolism, or breakdown of folic and humic acid (Albanell et al., 1988; Chen and Griffiths, 1988). Similar results on vermicomposting of cow manure, fruit, and vegetable wastes have been reported by Azizi et al. (2008), Gunadi and Edwards (2003) and Mitchell (1997).

\section{Conclusions}

This study results indicate the potential for vermicomposting of S or SB wastes in combination with cow manure and using earthworm E. foetida as an alternative technology for the recycling of this type of waste. Further studies for investigating the possibility of using S and SB in combination with other livestock wastes are required.

Acknowledgements. The authors thank the Agricultural Research and Education and Extension Organization for their financial support. We also thank our colleagues from the Ornamental Plants Research Station of Lahijan for their help. 


\section{REFERENCES}

[1] Albanell, E., Plaixas, J., Cabreo, T. (1988): Chemical changes during vermicomposting of sheep manure mixed with cotton industrial wastes. - Biology and Fertility of Soils 6: 266- 269.

[2] Anderson, J. P. E. (1982): Soil Respiration. - In: Methods of Soil Analysis (Page, A. L. Ed), Madison, Agronomy, ASA-SSSA, USA.

[3] Arancon, N. Q., Edwards, C. A., Bierman, P., Melzger, A. D., Lee, S., Welch, C. (2005): Effect of vermicompost on growth and marketable fruits of field-grown tomato, peppers and strawberries. - Bioresource Technology 47: 731-735.

[4] Atiyeh, R. M., Yardim, Y., Edwards, C. A., Metzeger, J. D. (2004): Influence of earthworm-processed pig manure on the growth and yields of greenhouse peppers. Bioresource Technology 93: 139-144.

[5] Atiyeh, R.M., Dominguez, J., Subler, S., Edwards, C.A. (2000): Changes in biochemical properties of cow manure during processing by earthworms (Eisenia andrei . Bouché ) and the effects on seedling growth. - Pedobiologia 44:709-724.

[6] Azizi, P., Khomami, A. M., Mirsoheil, M. (2008): Influence of cow manure vermicompost on growth of Dieffenbachia. - Ecology Environment and Conservation 14 (1):1- 4 .

[7] Bautista, J. M., Kim, H., Ahn Dae-Hee, Z. R., Young-Sook, O. (2011): Changes in physicochemical properties and gaseous emissions of composting swine manure amended with alum and zeolite. - Korean Journal of Chemical Engineering 28(1): 189-194.

[8] Bremner, J. M., Mulvaney, C. S. (1982): Nitrogen total. - In: Page, A. L., Miller R. H., Keeney D. R. (Eds). Methods of soil analysis: American Society of Agronomy, Madison, pp. 575-624.

[9] Bremner, J. M., Mulvaney, R. G. (1982): Nitrogen total. - In: Page, A.L., Miller, R.H., Keeney, D.R. (Eds.) Method of Soil Analysis. American Society of Agronomy, Madison. Pp. 575-624.

[10] Chaudhari, P. S., Bhattacharjee, G. (2002): Capacity of various experimental diets to support biomass and reproduction of Perionyx excavatus. - Bioresource Technology 82: 147-150.

[11] Chen, P. L. S. , Griffiths, O. A. (1988): The vermicomposting of pre-treated pig manure. - Biological Wastes, 24: 57-69.

[12] Edwards, C. A. (1988): Breakdown of animal, vegetable and industrial organic wastes by earthworms. - In: Edwards, C.A., Neuhauser, E.F. (Eds.) Earthworms in waste and environmental management. SPB Academic Publishing, Hague, pp. 21-31.

[13] Edwards, C. A. , Bohlen, P. J. (1996): Biology and Ecology of Earthworms. Third Ed. Chapman and Hall, London.

[14] Edwards, C. A., Fletcher, K. E.(1988): Interaction between earthworms and microorganisms in organic matter breakdown. - Agriculture, Ecosystems and Environment 24:235-247.

[15] Edwards, C.A., Dominguez, J. , Neuhauser, E. F. (1998): Growth and reproduction of Perionyx excavatus (Per.) (Megascolecidae) as factors in organic waste management. Biology and Fertility of Soils 27: 155-161.

[16] Grapelli, A., Tomati, U., Galli, E. (1983): Vermicomposting of combined sewage sludge and municipal refuse. - In: Proc Int Symp on Agriculutral and Environmental Prospects in Earthworm Farming, Rome, Italy. pp : 73-80.

[17] Gunadi, B., Edwards, C. A. (2003): The effect of multiple applications of different organic wastes on the growth, fecundity and survival of Eisenia foetida (savigny) (Lumbriciclae). - Pedobialogia 47 (4): 321-329.

[18] Gunadi, B., Blount, C., Edwards, C. A. (2002): The growth and fecundity of Eisenia foetida (savigny) in cattle solids pre-composted for different periods. - Pedobiolagia 46(1): $15-23$. 
[19] Hand, P., Hayes, W. A., Frankland, J. C., Satchell, J. E. (1988): The vermicomposting of cow slurry. - Pedobiologia 31: 199-209.

[20] Hartenstein, R. , Hartenstein, F. (1981): Physico-chemical changes affected in activated sludge by the earthworm Eisenia foetida. - Journal of Environmental Quality 10: 377382.

[21] Horwitz, W. (1980): Official methods of analysis of the Association of Official Analytical Chemist, 13th Ed. - Assoc. Off. Anal. Chem., Arlington, Va.

[22] Houba, V. J. G., Lee, V. D., Navozamasky, I. , Walgina, L. (1989): Soil and plant analysis -a series of syllabi. - Wageningen Agriculture University.

[23] Kale, R. D., Bano, K. , Krishnamoorthy, R. V. (1982): Potential of Perionyx excavates for utilization of organic wastes. - Pedobiologia 23: 419-425.

[24] Loh, T. C., Lee, Y. C., Liang, J. B. , Tan, D. (2004): Vermicomposting of cattle and goat manures by Eisenia foetida and their growth and reproduction performance. Bioresource Technology 96: 11-114.

[25] Lubbers, I. M., Groenigen, K. J. V., Fonte, S. J., Six, J., Brussaard, L., Groenigen, J. W. V. (2013): Greenhouse-gas emissions from soils increased by earthworms. - Nature Climate Change 3:187-194.

[26] Mitchell, A. (1997): Production of Eisenia foetida and vermicompost from feedlot cattle manure. - Soil Biology and Biochemistry 29: 763-766.

[27] Murphy, J., Riley, J. P. (1962): A modified single solution method for the determination of phosphate in natural waters. - Analytica Chimia Acta 27: 31-36.

[28] Ndegwa, P.M. , Thompson, S.A. (2001): Integrating composting and vermicomposting the treatment and bioconversion of biosolids. - Bioresource Technology 76: 107-112.

[29] Nelson, D. W., Sommers, L. E. (1982): Total carbon and organic carbon and organic matter. - In: Page A. L, Miller, R.H., Keeney D.R. (Eds.) Method of soil Analysis: American Society of Agronomy, Madison, pp. 539-579.

[30] Neuhauser, E. F., Hartenstein, R., Kaplan, D. L. (1980): Growth of the earthworm Eisenia foetida in relation to population density and food rationing. - OIKOS 35: 93-98.

[31] Pichtel, J. R., Hayes, J. M. (1990): Influence of fly ash on soil microbial activity and populations. - Journal of Environmental Quality 19:593-597.

[32] Reeh, U. (1992): Influence of population densities on growth and reproduction of the earthworm Eisenia andrei on pig manure. - Soil Biology and Biochemistry 24: 1327-1331.

[33] SAS Institute ( 2001): SAS Procedures Guide, Version 8, SAS Institute, Cary.

[34] Satchell, J. E. (1967): Lumbricidae. Pp. 259-32.2. - In: Burges, A., Raw, F. (Eds) Soil biology, Academic Press, New York.

[35] Silvana, M. C., Sueli, S. F., Claudio. A. (2002): Microbial biomass and microcalorimetric methods in tropical soils. - Thermochimica Acta 394: 145-154.

[36] Tomati, U., Grappelli, A., Gallii, E. (1987): The presence of growth regulators in earthworm-worked wastes. - In: Bonvicini Paglioi, A.M., Omodeo, P. (Eds.) On Earthworms. Proceedings of International Symposium on Earthworms. Selected Symposia and Monographs, Unione Zoologica Italiana, 2, Mucchi, Modena, pp. 423-435.

[37] Verdonck, O. , Gabriels, R. (1992): Reference method for the determination of physical and chemical properties of plant substrates. - Acta Horticulturae 302: 169-179.

[38] Zhang, B., Li, G., Shen, T., Wang, T. , Sun, Z. (2000): Changes in microbial biomass C. $\mathrm{N}$ and $\mathrm{P}$ and enzyme activities in soil incubated with the earthworms Metaphire guillelmi or Eisenia foetida. - Soil Biology and Biochemistry 32:2055-2062.

\section{ELECTRONIC APPENDIX}

This article has electronic appendices with basic data. 